\title{
Teacher -Factor Panacea to Educational Degradation in Ekiti State Pre-Tertiary Institutions
}

\author{
${ }^{1}$ Ogunlade Joseph Olurotimi (phd), ${ }^{2} \mathrm{Mr}$. Eegunjobi John Olutope \\ ${ }^{I}$ Faculy of Education, Islamic University In Uganda \\ ${ }^{2}$ College of Education, Ikere Ekiti, Ekiti State.Nigeria.
}

\begin{abstract}
The study investigated school and teacher effectiveness issues in Ekiti State, Nigeria. As a descriptive survey, teachers and students in senior secondary schools in Ekiti State constituted the study population. The sample comprised of 288 teachers and 1920 students, randomly selected from 32 schools that were stratifiedly selected and drawn from 16 local government areas in Ekiti State..Four different measuring instruments were used to collect data. The data collected were subjected to statistical analysis involving ANOVA, Correlations and Regression. Findings from the study showed among others that, teachers possessed adequate qualifications but their teaching was not effective. There was a significant positive relationship between teacher effectiveness and school effectiveness, and the result of multiple regression analyses indicated that independent variables like teacher's classroom management skills and qualifications made significant positive contributions to teacher effectiveness. The study recommended that government should do more to monitor implementation stages of its education policy. Serial and genuine implementation of policy is as important as its formulation. The inspectorate division of the ministry of education should take seriously the monitoring of what goes on in our classrooms, especially schools in rural areas where student as expect "miracle" passes.
\end{abstract}

\section{Introduction}

Education is adopted as an instrument for effecting national development and growth so as to produce citizen that are dynamic both in thought and deeds, self-sufficient, effective, and united and show civil responsibility [11]. Education is regarded as the greatest hope of any nation especially for a developing country like Nigeria, which should not be left in the hand of mediocre. The increasing awareness of the importance of education to the upliftment of the individual and societal standard has awakened in people and nation a conscious effort of their meager resources to acquiring qualitative education.

This has made education to be seen as an investment into which resources are expended by individuals and government. An investment is justified when the gains are greater than those derivable from those alternative investments. This has also made the value of a sound educational policy lies in its effective implementation and it is the teacher who transforms the policy into practice. Adu [5] asserted that the quality of a school and that of the teaching personnel so permeate each other that a vicious circle is created in analysis of their inter-relationship in which we cannot have a good school unless we have good teachers. Hence, an inspiration for good teachers should be a keystone for any national system of education.

The process of learning is largely determined by the teacher (class activity, lesson presentation, assessment techniques etc). The teacher therefore is the singular most important variable in the teachinglearning process. According to Ambasht [8], Jegede [12] and Lassa [13],teachers are the main determinant of the quality in education especially in developing countries like Nigeria. Also, according to the National Policy on Education [11], no educational system may rise above the quality of its teachers. Abdulahi and Onasanya [1] opined that inadequate supply of effective teachers becomes the core of educational problem because there is a direct link between quality of education and quality of teachers.

Perhaps it is in recognition of the positive relationship between teacher qualification and academic performance that Obameata [15] suggested an improvement in the staffing situation in terms of quality and quantity with a view to improving learning and raising the level of achievement in Nigerian schools. Also, Adesina [4] remarked that the heart of Nigerian educational system is the teacher. According to him, the teacher is and will continue to be both the major indicator and the major determinant of quality education. In some situations where there are inexperienced teachers, and students are maltreated, students may loose interest in their teachers, which tend to increase stagnation or school dropout.

The teacher is regarded as one of the greatest inputs into the educational system. Teachers are recognized as the most important school factor affecting student achievement. (Sass, Hannaway, Xu, Figlio, and Feng [18]. Teachers facilitate effective teaching and learning. At the same time, poor academic performance of the students can be blamed on the teachers. This is because the ability of a teacher determines his capabilities based on the level of his exposure through training and skills learnt. In consonance with the above, Ajayi [9] claimed that the poor quality of teachers in Nigerian schools can be traced to poor training received in teacher 
training institutions through obsolete materials and equipment. According to Nwagwu [14], hostile school environments that are joyless with pretty oppressive demands contribute to the dropout of learners from school. The teacher is one of the environmental factors within the school.

A teacher is thus considered to be a leader whose quality is seen in his ability to initiate ideas and structure, organize and manage his classroom, increase students' skill and knowledge, prepare and present interesting and yet challenging lessons, guide students to success and have the ability to assess and evaluate students' learning correctly.

Many studies have examined teacher effectiveness and students academic performance. Such studies include those of Okpala and Onocha [16], and Williams [19] established a significant link between pupil's performance and teacher effectiveness, and between teacher performance and classroom atmosphere.

This research will be the major contribution to the teacher and school effectiveness study which will be for the purpose of assessing performance of teachers and schools in the state of teaching and learning. This research is significant in assessing the quality variations in our schools and classrooms, such as students' behavior, school tone, teacher proficiency, parents and community involvement and government policy. Assessing teachers and school effectiveness will be beneficial to students, teachers schools and communities in that it affords the opportunity to measure and ascertain the levels of common features of effective school such as intellectual expectation of students, professional proficiency of teachers, climate of schools and community participation in educational development of students.

\section{Rationale for the Study.}

The decay in the Nigerian schools has been described as worrisome. According to Adu [4], the performance of students does not encourage stakeholders at all levels of education. Majority of students admitted do not graduate at appropriate time. Secondary schools are no longer effective in terms of the cognitive, affective and psychomotor domains of learning. Results of students in SSCE showed poor performance year in year out in core subjects, which is an indication that all is not well within the system.

This research is majorly concerned with school and teacher effectiveness variables in Ekiti State, Nigeria. School and teacher variables are among the important paradigms that pose considerable challenges to educational effectiveness in general and student outcomes in particular. Hence, this study is an attempt to critically assess school and teacher effectiveness issues in secondary school in Ekiti State, Nigeria. The study examined: The school effectiveness in the areas of students outcomes, characteristics of schools, school goal, school tone, student's behavior, teacher proficiency and parents/community involvement. The teacher effectiveness, as in quality education, teachers' qualification, teacher preparation, teacher presentation, classroom management and assessment skill and efficiency in Ekiti State, Nigeria.

Hypotheses: Based on the problem of this study, the following hypotheses were raised:

Ho1: There is no significant relationship between teacher effectiveness and school effectiveness.

Ho2: Teacher preparation, presentation, qualification, classroom management

And assessment skills do not significantly contribute in to teacher effectiveness in Ekiti State.

\section{Methodology}

The researchers employed ex-post-facto and descriptive research designs of survey type. It is an expofacto because there was no manipulation of variables but a study of independent factors as they influenced or affected effectiveness issues in schools and among teachers in Ekiti State.The population for the study consisted of all the secondary school students and teachers in ekiti state. The state has 16 local government areas. Using stratified random sampling technique, two schools were randomly selected from each stratum (local government area) to give a total of 32 schools, the totals of 288 teachers were drawn from the 32 schools. This number was made up of 9 teachers from each school in which 3 teachers each were drawn from the departments of sciences, arts and business. Also, 60 students were randomly selected from each school from ss1, ss2 and ss 3 to give a total of 1920 students. Hence, the study involved 288 teachers, and 1920 senior secondary school students drawn from 32 secondary schools. Four types of instrument were constructed. These are

1. Teacher Self Report Inventory (TSRI)

2. Teacher Effectiveness Questionnaire (Students Version)(TEQ)

3. School Effectiveness Questionnaire(SEQ)

4. Documentary Effectiveness Inventory (DEI)

Three out of the four instruments were subjected to validity with the help of experts in the areas of educational psychology and educational evaluation. The instruments were subjected to face contents and construct validity the fourth instruments; the documentary evidence inventory was not subjected to validity procedure because it has already been validated in a previous study by Adu (2010) the reliability of the three instruments was estimated using cronbach alpha to ensure internal consistency. The reliability coefficients 
obtained were tsri $=0.88$, teq $=0.92$ and seq $=0.87$, data on students' academic performance were collected from the results of secondary school students in their West African School Certificates Examination (WASCE) covering a period of five academic sessions, 2007/2008 to 2010/2011.

Responses of students from sampled schools and their teachers and heads of schools to questionnaire items were collected and scores were assigned to each point on the likert- scale as follows: strongly agree $=4$, agree $=3$, disagree $=2$, strongly disagree $=1$.teacher self report inventory (tsri) was scored as follows; always $=4$, sometimes $=3$, seldomly $=2$, and rarely $=1$, data were analyzed using inferential statistics such as pearson product moment correlation coefficient, student-t test, correlation matrix, regression and anova were used.

\section{Result}

In testing this hypothesis, data on teacher effectiveness and school effectiveness were used. Data on teacher effectiveness were collected using the teacher effectiveness questionnaire (teq). The average of teachers' score was calculated as the rate of teacher effectiveness in each school. Data on school effectiveness were collected using responses to the school effectiveness questionnaire. The average score was recorded for each school. The results are presented in table 1

Table 1: Test of Relationship between School and Teacher Effectiveness

\begin{tabular}{|l|l|l|l|l|l|l|}
\hline Variables & $\mathrm{N}$ & $\mathrm{X}$ & $\mathrm{Sd}$ & $\mathrm{Df}$ & $\mathrm{R}$ cal & $\mathrm{R}$ tab \\
\hline $\begin{array}{l}\text { Teachers } \\
\text { Effectiveness }\end{array}$ & 32 & 2.48 & .31823 & & & \\
\cline { 1 - 1 } $\begin{array}{l}\text { School } \\
\text { Effectiveness }\end{array}$ & 32 & 2.45 & .30761 & 31 & .641 & .448 \\
\hline
\end{tabular}

$\mathrm{P}<0.05$

Table 1 shows the relationship between teacher effectiveness and school effectiveness. The results obtained from the analysis show that the value of $r$-cal (.641) is greater than $r$-tab (.44) at 0 -05 level of significance. The null hypothesis is therefore rejected. This means that there is a significant relationship between teacher effectiveness and school effectiveness.

In testing this hypothesis, teachers effectiveness was measure using the teacher self report inventory (tsri).the result are presented in the tables $2 \mathrm{a}, \mathrm{b}, \mathrm{c}$ and $\mathrm{d}$.

Table 2a: Correlation Matrix of the Relationship Among Teachers' Preparation, Presentation, Qualification, Classroom Management, Assessment Skills and Teacher Effectiveness

\begin{tabular}{|c|c|c|c|c|c|c|}
\hline \multirow[b]{2}{*}{ Matrixes } & \multicolumn{6}{|c|}{ Relationship } \\
\hline & 1 & 2 & 3 & 4 & 5 & 6 \\
\hline $\begin{array}{l}\text { Teachers } \\
\text { Effectiveness }\end{array}$ & 1 & & & & & \\
\hline Presentation & $.197 * *$ & 1 & & & & \\
\hline Preparation & .067 & .024 & 1 & & & \\
\hline Qualification & $.118^{* *}$ & $.154 *$ & .092 & 1 & & \\
\hline $\begin{array}{l}\text { Classroom } \\
\text { Management }\end{array}$ & $.234 * *$ & $.340^{*}$ & .021 & .106 & 1 & \\
\hline $\begin{array}{l}\text { Assessment } \\
\text { Skills }\end{array}$ & .005 & .211 & .025 & $.118^{*}$ & .027 & 1 \\
\hline
\end{tabular}

Table 2a shows the relationships between each pair of variables examined in this study. There is a significant relationship between teachers' effectiveness and teacher presentation, (.197).

There is also significant relationship between qualification and teacher effectiveness (.118) and between classroom management and teacher effectiveness (.234).however, there are no significant relationships between teacher preparation and teacher effectiveness and between the assessment skills and teacher effectiveness. Interestingly, there are significant correlations between teacher presentation and teacher qualification and also with classroom management.

Table 2b: Multiple Regressions Analysis Model Summary of Predictor Variables and Teacher Effectiveness

\begin{tabular}{|l|l|l|l|}
\hline $\mathrm{R}$ & $\mathrm{R}$ & Adjusted & Standard error \\
\hline 0.436 & 0.190 & 0.175 & 0.7405 \\
\hline
\end{tabular}

Table $2 b$ shows the combined effects of independent variables in explaining the dependent variable (teacher effectiveness). The independent variables were regressed on the dependent variables. As shown in table (2b) $\mathrm{r}$ square $(\mathrm{r} 2)$ which is the coefficient of determination i.e. $\mathrm{R} 2 \times 100$, gives the proportion of the proportion of the variance that are explained by the classroom management, and assessment skills. The predictors have a multiple correlation of 0.436 with teacher effectiveness. The combinations of the predictors are able to account 
for $19 \%$ of the variance in teachers' effectiveness. Hence, it is concluded that there were other factors which also contribute to the variance in teacher effectiveness.

Table2c: Analysis of Variance for the Model

\begin{tabular}{|l|l|l|l|l|l|}
\hline $\begin{array}{l}\text { Source of } \\
\text { Variation }\end{array}$ & $\begin{array}{l}\text { Sum of } \\
\text { Squares }\end{array}$ & Df & $\begin{array}{l}\text { Mean } \\
\text { Square }\end{array}$ & F & Sign \\
\cline { 1 - 4 } Regression & 36.208 & 5 & 7.242 & \multirow{2}{*}{13.203} & \multirow{2}{*}{0.000} \\
\cline { 1 - 5 } Residual & 154.667 & 282 & .545 & & \\
\cline { 1 - 4 } Total & 190.875 & 287 & & & \\
\hline
\end{tabular}

Table $2 \mathrm{c}$ shows that the predictor variables show dependence on the criterion variable (teacher effectiveness) as f-ratio of 13.203 which is significant at $0.000(\mathrm{p}<0.05)$ is observed. In other words, the predictors have significant influence on the dependent variable (teacher effectiveness). Hence, the null hypothesis which states that teachers' preparation, presentation, qualification, classroom management and assessment skills have no significant influence on teacher effectiveness is rejected in favor of the alternative hypothesis.

Table 2d: Test of Significance of Regression Coefficients and T-Values of the Predictors on the Criterion Variable.

\begin{tabular}{|l|l|l|l|l|l|}
\hline Variables & $\begin{array}{l}\text { Un standardized } \\
\text { Coefficients }\end{array}$ & $\begin{array}{l}\text { Standard } \\
\text { Error }\end{array}$ & $\begin{array}{l}\text { Standardized } \\
\text { Coefficients } \\
\text { Beta }\end{array}$ & T & Sign \\
\hline Constant & 1.843 & .281 & & & \\
\hline Class management & .151 & .052 & .166 & 2.887 & .004 \\
\hline Presentation & .145 & .051 & .154 & 2.847 & .005 \\
\hline Qualification & .136 & .061 & .123 & 2.255 & \\
\hline Assessment & -.185 & .050 & -.205 & -3.730 & .000 \\
\hline Preparation & -.247 & .056 & -.247 & -.4385 & .000 \\
\hline
\end{tabular}

The parameter estimate on table $2 \mathrm{~d}$ shows that partial correlation coefficients of class management, presentation and qualifications have positive relationships with teacher effectiveness. Those of preparation and assessment skills have negative relationships. All the relationships are significant at $p>0.05$ level of significance, the table also shows the relative contributions of each predictor to the criterion variables. The standardized regressed coefficients (beta) were used to determine relative contributions of each variable to the explanation of teacher effectiveness. Class management made the highest contribution to the criterion variable (teacher effectiveness). This is followed by teacher presentation and teacher qualification. But teacher preparation and assessment skills made negative contributions, thus, the regression equation of the variables is teacher effectiveness $=1.843+.151$ class management +.145 presentation +.136 qualification -185 assessment skills -247 preparation.

The above regression equation indicates that given that all other variables are kept constant, then every increase of one unit in class management will increase teacher effectiveness by 0.151 . Also every increase of one unit in teacher presentation and qualification will produce a corresponding increase of 0.145 and 0.136 respectively in teacher effectiveness. However every one unit increase in teachers' assessment skill and preparation will result in reduction of 0.185 and 0.247 respectively in teacher effectiveness.

\section{Discussion}

The result of the study have shown that for five consecutive years in Ekiti State, only $17.71 \%$ of secondary school students obtained 5 credit passes and above, while $29.32 \%$ had 4 credit passes and $53.52 \%$ had 3 credit passes or less in the senior school certificate examinations. The result indicates that schools were less effective in terms of students' academics performances. The implication is that only those that had 5 credits and above $(17.71 \%)$ would qualify for University education. Perhaps, others $(82.3 \%)$ would dropout or engage in menial jobs. These findings are support of Ekundayo [10] who recorded that schools in Ekiti State were not effective in the area of academic performance and that of Adu [5] who worked on internal efficiency of Colleges of Education in Nigeria. This finding revealed that the Colleges of Education were also not effective. These finding are consistent with the finding by Babalola [7], who found high dropout rates in secondary schools in Ekiti State, Nigeria. The findings are also in consonance with those of other researchers [Afolabi,[6].these are contrary to the report of Adeyemi [4] who did research on school-based variables and internal efficiency of Secondary Schools in Ondo State and found that the Secondary schools in Ondo State Nigeria were 85\% internally efficient.

The result of the study revealed the relative contributions made by teacher variables (i.e. Presentation, preparation, qualification, and classroom management and assessment skills) to teacher effectiveness in ekiti state. The findings isolated class management as the highest contributor to teacher effectiveness followed by teacher qualifications. The correlation matrix in table $2 \mathrm{a}$ also indicated that significant relationships existed 
between teacher presentation and qualification and also between teacher presentation and class management. The facts suggests that an effective teacher should be one who possesses the right qualifications, presents his lessons diligently to a well managed group of students. Hence an effective teacher should be knowledgeable, resourceful and an adept manager of classroom environment. It is evident that effective teaching and learning cannot take place in disorganized or poorly managed environment.

The much talked-about fall in standard of education in schools in nigeria is often attributed to teacher ineffectiveness .however, Oladunni [17] observed that many people joined the teaching profession not as a long life vocation, but out of necessity awaiting an opportunity to use it as a spring board to other jobs while others remain and constitute a class of disgruntled teachers. It is certain that those teachers without adequate qualifications or interest cannot be effective in their teaching and hence students would not benefit much from a situation where teachers are not components. On qualification issues, Adeyemi and Adu [3] found that qualifications of teachers have relative contribution to student outcome, while Adeyemi's [3] research on schools based variables and internal efficiency confirmed that teacher's qualification was a good predictor of school internal efficiency.

\section{Conclusion}

Considering the finding of this research, the researchers are of the opinion that the falling standard of education in Nigeria in general and in Ekiti State in particular may be alleviated by government finding ways and means to enhance school and teacher effectiveness. This can be done by monitoring what goes on inside the classroom. It is imperative that parents become active participants in the education of their wards right from the formulation of government policies through planning stages, implementation of school set goals, students, behaviors, teachers' proficiency and finally students' outcomes.

\section{Recommendations}

Based on the finding of this study, the following recommendations are made: government should do more to monitor implementation stages of its education policy. Serial and genuine implementation of policy is as important as its formulation. The inspectorate division of the ministry of education should take seriously the monitoring of what goes on in our classrooms, especially schools in rural areas where student as expect "miracle" passes. It is a common practice that most senior teachers are often removed from classrooms to be made Principals or HODs. Thereafter, such teachers are preoccupied with administrative matters. These practices reduce the impact of teacher effectiveness on students learning and consequently on academic attainment. This practice should be reviewed because it is detrimental to students' academic performances. A policy should be put in place to ensure that the senior and experienced teachers teach once a while or partake in tutorials.

\section{References}

[1]. Abdullahi, O. F. \& Onasaniya, S.A (2010). Effect of Teacher Effectiveness on Kwara State Secondary School Students' Achievement in Mathematics. Medwell Journals. Scientific Research Publishing Company. Vol. 5 issue 4p286-292.

[2]. Adeyemi, T.O. (2012).Portability of Teacher Effectiveness Across School Settings Calder Working Paper no.77-5796. www.caldercenter.com

[3]. Adeyemi, T. O.(1998).School and Teacher Variables Associated with the Performance of Students in the Senior Secondary Certificate Examinations in Ondo State Nigeria. Ph.D Thesis (unpublished). University of Hull, United Kingdom.

[4]. Adesina, S.(1983). Education for Development. The Challenges of the 1980s. In Adesina S. Akinyemi k. And Ajayi K. (eds). Nigerian education trends and issues. Ile-ife university of ife.

[5]. Adu,E.T. (2010). School-Based Variables and Internal Efficiency of Colleges In education in nigeria. Unpublished ph.d thesis of faculty of education.unad.

[6]. Afolabi a.o. (2006). Faundamentals of Systems Analysis in Education. Lagos, Balobay Publications.

[7]. Babalola, M Y. (2003). Relationship between Selected Variables and Student Performance in Primary Schools in Sokoto State. Unpublished M. Ed thesis of UNILORIN.

[8]. Ambasht,n.k. (2003).Teacher Education in the New Millennium Challenges and Strategies. National Teachers Institute,

[9]. Ajayi, T. (1995) an Examination for Pupils Withdrawal from Universal Primary Education(upe) Scheme in Ogun state Osu Journal of Educational Studies 2(1),107

[10]. Ekundayo, H. T. (2009). Institutional Factors as Correlates of Effectiveness in Secondary Schools in Southwest Unpublished PH D. Thesis, University of Ado- Ekiti, Ekiti State.

[11]. Federal Republic of Nigeria (2004) .Nigeria Policy on Education Lagos, Nigeria, NERDC Press P. 39.

[12]. Jegede, O. (2003). Acelebration of Teacher Education and Open and Distance Learning in Nigeria: Attainments, Challenges and Strategies In NTI,Kaduna, Teacher Education in Nigeria: Past, Present and Future,Kaduna, National Teacher Institutes p11-36

[13]. Lassa. P (2000). Teacher Production: a Focus on Nigeria. In the State of Education in Nigeria, Abuja UNESCO.

[14]. Nwagwu N.A. (1976). Upe: issues, Prospects and Problems. Benin

[15]. Obemeata, J.O. (1992). Raising the Standart of Performance in Public Examinationin Nigeria Paper Presented at the WAEC Symposium on Raising the Standard of Performance in Public Examinatios, Universsity of Ibadan, Ap

[16]. Okpala, N. P. \& Onocha, (1995). Students Factor as Correlates of Achievement in Physics Education:J.Br.Ins.Phys,6:361-366.

[17]. Oladunni,M.O.(1999).Attitude Profile of Mathematics Teacher Towards Teaching of Difficult Topics in Mathematics.Africana Journal of Educational Research. Vol.5,no2 16-23

[18]. Sass, Hannaway, Xu, Figlio, and Feng (2011). Teacher Effectiveness in Relation to Self Concept of Elementary School Teacher in isrj vol. 1 no.3 pg 13-14. Ekutage (saheeren and crèmes 1989 acdemics;2012).

[19]. Williams T.D (1965)Westage rate and Teacher Quality in Guatemalan Schools. In comparative educational review 9,46-52. 